\title{
Pathogenesis of Small Airways in Asthma
}

\author{
Qutayba Hamid \\ Meakins Christie Laboratories, McGill University, Montreal, Que., Canada
}

\section{Key Words}

Nocturnal asthma $\cdot$ Small airways $\cdot$ Remodeling

\begin{abstract}
Asthma is a lung disease characterized by inflammation and remodeling of the airways. It is now widely accepted that airway inflammation and remodeling occur not only in the central airways but also in the small airways and even in the lung parenchyma. Inflammation of the distal lung can be observed even in mild asthmatics with normal or noncompromised lung function. Moreover, the small airways and the lung parenchyma can produce many Th2 cytokines and chemokines involved in initiation and perpetuation of the inflammatory process. In addition, the distal parts of the bronchial tree have been recognized as a predominant site of airflow obstruction in many asthmatics. In fact, the inflammation at this distal site has been described as more severe when compared to the large airway inflammation, and evidence of remodeling in the lung periphery is emerging. Recognition of asthma as a disease of the entire respiratory tract has an important clinical significance, highlighting the need to also consider the distal lung as a target in any therapeutic strategy for effective treatment of this disease.
\end{abstract}

Copyright $\odot 2012$ S. Karger AG, Basel
(C) 2012 S. Karger AG, Basel

0025-7931/12/0841-0004\$38.00/0

Fax +4161306 1234

E-Mail karger@karger.ch

www.karger.com
Accessible online at: www.karger.com/res

\section{Introduction}

Asthma is a chronic inflammatory disease of the lung characterized by episodic airway obstruction and increased bronchial responsiveness. The major pathological and structural features of asthma include epithelial shedding, increased airway smooth muscle mass (due to hypertrophy, hyperplasia, or migration), mucous gland hyperplasia, sub-epithelial fibrosis, and infiltration of the bronchial wall with inflammatory cells [1]. The concept that inflammation is a major component of asthmatic pathology was established more than 100 years ago, from studies of autopsy specimens used to assess the macroscopic morphological and histological changes within the large asthmatic airways [2]. That the distal airways and the lung parenchyma play a role in asthma has been suggested by experiments in which the physiological behavior of the lung has been investigated $[3,4]$. These early studies, originally conducted at the Meakins-Christie laboratories, focused attention on the role of the distal airways in asthma; however, investigation in this area lagged because of the difficulties in examining these peripheral structures directly. Since then, the development of new techniques of tissue sampling and of physiological measurements has allowed assessment of the role of the lung periphery, and distal airways have now been recognized as a predominant site of airflow obstruction in many asthmatics [5-8]. Introduction of fiber-optic bron-

Qutayba Hamid, MD, PhD

Meakins Christie Laboratories, McGill University

3626 St. Urbain Street

Montreal, QC H2X 2P2 (Canada)

Tel. +1 514398 3864, ext. 00143, E-Mail Qutayba.Hamid@ McGill.ca 
Fig. 1. Small airways of an asthmatic subject with inflammation indicated by immunocytochemistry staining of major basic protein (MBP).
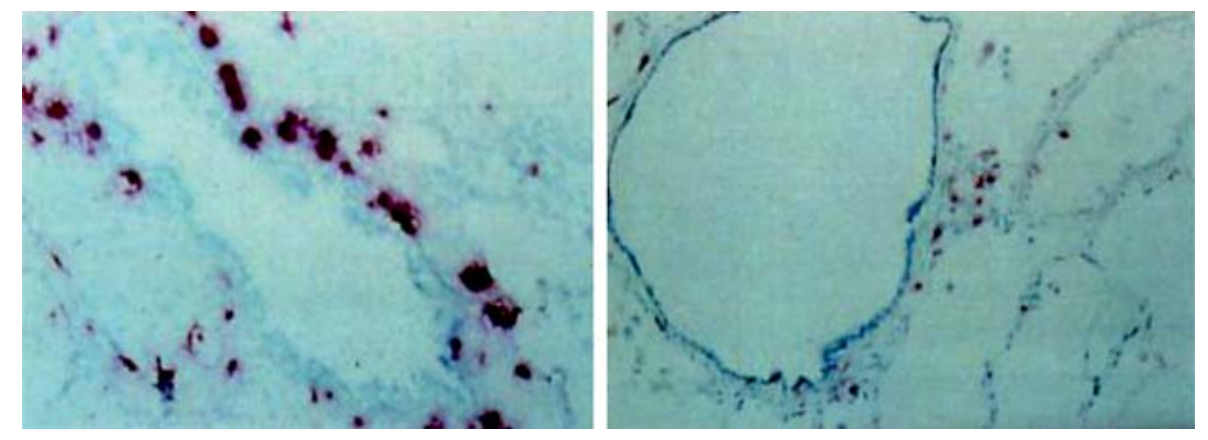

choscopy, for example, has enabled us to obtain small endobronchial or transbronchial biopsies from the large and small airways of human asthmatic patients. Together with the recent applications of molecular pathological techniques, including immunocytochemistry and in situ hybridization to biopsies and bronchoalveolar lavage fluid, these technological advances have had a profound impact on our understanding of the pathogenesis of bronchial asthma $[9,10]$. Recent studies utilizing these approaches in surgically resected lung tissue [11-13], postmortem lung specimens [14-16], and transbronchial biopsies $[17,18]$ have demonstrated that similar but more severe inflammatory and structural changes are also occurring in the distal lung $[15,19,20]$ and extending into the lung parenchyma of asthmatic patients [17].

It is now accepted that in asthmatics recruitment of inflammatory cells, in particular eosinophils and T cells, also occurs in the distal lung $[11,12]$ and the lung parenchyma [17]. In addition, in asthmatics there is an abundance of Th2-type cytokines and chemokines present at this distal site $[12,13]$. These pathological findings may prove to be extremely important as the total volume and combined surface area of the distal airways are much greater than the combined volume and the surface area of the large airways [21]. This clearly suggests that any changes developing in the distal lung and the parenchyma in patients with asthma will have a dramatic effect on the pathophysiology and treatment of this disease. The current therapeutic challenge is to develop better inhalation technologies to improve the delivery of anti-inflammatory agents to the lung periphery. This review article aims to evaluate the pathological and physiological evidence presented in the literature to date, which outlines the contribution of the distal lung and the lung parenchyma to the pathophysiology of asthma.

\section{Inflammation in the Small Airways}

Asthma is characterized by infiltration of central airways with inflammatory cells and upregulation of Th2type cytokines, in particular IL-5, IL-4, IL-9, and IL-13. Largely these observations stem from studies that have sampled central airways, as bronchoscopic sampling has been largely limited to proximal airway sites only. For this reason, the pathologic process that occurs in the distal airways has been less well defined. The early studies surrounding the role of the peripheral or the distal airways in the pathophysiology of asthma originated from autopsy studies $[14,15,22]$. These studies demonstrated that the entire length of the airway is involved in asthma and not only the central airways as originally proposed [7, 23-25]. Carroll et al. [14] carefully examined the distribution of inflammatory cells throughout the bronchial tree of both fatal and nonfatal cases of asthma and showed increased numbers of lymphocytes and eosinophils uniformly distributed throughout the large and distal airways of mild and severe asthmatics when compared to control cases. Similar infiltration of T cells, macrophages, and eosinophils into the proximal and distal lung tissues has also been reported in rare cases of sudden asthma death (dying within $1 \mathrm{~h}$ after the onset of their symptoms) [15] and in soybean dust-induced asthma [20].

Using resected lung specimens from asthmatic and nonasthmatic patients who underwent thoracic surgery, we have similarly demonstrated that the inflammatory response in asthma is not restricted to the proximal airways but is also seen in the distal lung [11]. We reported an increased number of $\mathrm{CD} 3+\mathrm{T}$ cells and major basic protein $(\mathrm{MBP})+$ eosinophils not only in the large airways ( $>2 \mathrm{~mm}$ internal diameter) but also in the distal airways $(<2 \mathrm{~mm}$ internal diameter) of asthmatic patients when compared to healthy controls (fig. 1). In fact, a greater number of activated eosinophils was seen in the airways 
$<2 \mathrm{~mm}$ internal diameter than in the airways $>2 \mathrm{~mm}$ internal diameter, suggesting that a similar but more severe inflammatory process is present in the distal airways [26]. In the same cohort of patients, we have also shown increased IL-5 and IL- 4 mRNA-positive cells in the distal airways of asthmatic subjects compared to nonasthmatic controls [12] and, more importantly, the expression of IL-5 mRNA was increased in the distal airways compared to the large airways [12]. Numbers of cells expressing IL-2 and IFN- $\gamma$ mRNA remained unchanged in these subjects when compared to controls. Furthermore, simultaneous in situ hybridization and immunocytochemistry has demonstrated $85 \%$ of the IL- 5 mRNA-positive cells in the distal airways to be $\mathrm{CD} 3+\mathrm{T}$ cells, similar to the proportion found in the large airways (81\%) [12]. In addition, we have shown increased eotaxin and monocyte chemotactic protein-4 mRNA expression in the distal airway epithelium of asthmatics compared to nonasthmatics and we have found the number of chemokine-positive cells in the distal airways of these patients to correlate with the number of MBP + eosinophils at this same site [13].

The use of lung sections has allowed examination of the smooth muscle cells. Haley et al. [25] evaluated the distribution of CD45+ cells within the subepithelial regions of the airway wall and showed that the distal asthmatic airways had the majority of their CD45+ leukocytes and eosinophils in the 'outer' airway wall regions ('outer' defined as the area between the smooth muscle and the alveolar attachments), whereas the greatest density of eosinophils in the large asthmatic airways was in the 'inner' airway wall regions ('inner' area defined as the area between the epithelial basement membrane and the smooth muscle) [25]. These differences highlight the regional variations in inflammatory cell distribution within the asthmatic airway wall, and these differences appear to be disease specific as such variations were not observed in patients with cystic fibrosis [25]. The different regional distribution of inflammatory cells throughout the tracheo-bronchial tree may be attributed to the differences in mechanisms of inflammatory cell recruitment and/or differences in chemokine and cytokine production between these regions. These differences may influence the physiological response caused by local production of pro-inflammatory mediators. In support of this claim, increased expression of eotaxin, a potent eosinophil chemoattractant, has been documented in the airway epithelial layer of the peripheral airways of asthmatics [13]. The smooth muscle itself has been proposed as a site of chemokine production in the distal airways [25]. In patients who died of asthma, inflammation was found to extend well beyond the airway smooth muscle layer and is still significant around the pulmonary arterioles [27]. The introduction of transbronchial biopsies in research protocols has furthered our understanding of the role of inflammation of small airways in asthma. Kraft et al. [17] showed significant alveolar inflammation in patients with nocturnal asthma (NA), compared to patients with nonnocturnal asthma (NNA). In those studies, both proximal airway endobronchial and distal alveolar tissue transbronchial biopsies were performed in the same patient at 4:00 p.m. and 4:00 a.m. Patients with NA had increased numbers of eosinophils per unit of lung volume in their lung parenchyma at 4:00 a.m. compared to patients without NA. Additionally the NA patients had a greater number of eosinophils and macrophages in their alveolar tissues at 4:00 a.m. than at 4:00 p.m. Moreover, in NA patients, only alveolar but not central airway eosinophilia correlated with overnight reduction in lung function [17] and was associated with increased numbers of CD4+ cells in alveolar tissues of NA patients at 4:00 a.m. compared to NNA patients $[18,28]$. Although the number of CD4+ cells in the endobronchial lamina propria was higher than in the alveolar tissue, once again, only the alveolar CD4+ lymphocytes correlated with the predicted lung function at 4:00 a.m. ( $\mathrm{r}=$ $-0.68)$ and with the number of activated alveolar eosinophils (EG2+, $r=0.66)$ [18]. In this same group of patients, NA was associated with reduced glucocorticoid receptor (GR)-binding affinity, reduced proliferation of peripheral blood mononuclear cells, and decreased responsiveness to steroids when compared to NNA patients [29]. These studies have demonstrated that the increased numbers of CD4+ cells in alveolar tissue in NA patients, as well as reduced GR-binding affinity and reduced steroid responsiveness, may be responsible for orchestrating the eosinophil influx and exacerbation of symptoms in patients with NA. One of the proposed mechanisms which may beresponsible for this phenomenon is upregulation in the expression of GR- $\beta$ (glucocorticoid receptor- $\beta$ ), which has previously been reported in steroid-insensitive subjects with severe asthma [16]. Christodoulopoulos et al. [16] in our laboratory characterized the expression of GR- $\beta$ within the peripheral airways in cases of severe fatal asthma. They demonstrated the principal cells expressing GR- $\beta$ to be CD3+ T lymphocytes and, to a lesser extent, eosinophils, neutrophils and macrophages [16]. These results suggest that the increased number of GR$\beta$-immunoreactive cells in the distal airways of patients with fatal asthma may be associated with steroid resistance, potentially contributing to asthma mortality. 
Distal airway inflammation has been reported in severe symptomatic, steroid-dependent asthmatics [30]. Using endobronchial and transbronchial biopsies, Wenzel et al. [30] reported persistent proximal and distal airway inflammation in these patients. Although the number of eosinophils was similar between severe asthmatics and normal controls, severe asthmatics had high numbers and percentages of neutrophils in their bronchoalveolar lavage and endobronchial and transbronchial biopsy specimens when compared with mild-to-moderate asthmatics, and this despite aggressive treatment with steroids [30]. In cases of fatal asthma, inflammatory cells make up a higher proportion of the exudate that occludes the smaller airways than the exudate from the larger airways [31]. From this evidence, it is thought that the inflammatory cell density in the distal airways of severe asthmatics may relate to the peripheral airway obstruction characteristic of this disease. The distal airway inflammation may cause uncoupling of the parenchyma and airways due to the mechanical interdependence between these two compartments, leading to changes in overall lung mechanics in asthmatics. The degree and character of inflammation in the small airways can be directly compared to inflammation in the large conducting airways using invasive techniques such as bronchial and transbronchial biopsies on the same patient [32]. This approach has been used recently by a number of investigators to assess the distribution and phenotype of inflammatory cells, particularly mast cells, in the large and small airways of asthmatics. These studies have found that asthmatics have more mast cells in the distal lung compared to the large airways [33, 34]. These regional differences in mast cell numbers were not seen in healthy controls, and the mast cells of asthmatics expressed higher levels of the high-affinity IgE receptor FceRI and increased surface-bound IgE. These authors attributed the reduced density of mast cells in the large conducting airways to treatment with corticosteroids, since this treatment is known to reduce mast cell numbers in the central airways $[35,36]$. It can be concluded from these studies that IgE-mediated inflammatory reactions are not limited to the large airways but are also an important component of the disease in the distal lung. Therefore, targeting peripheral airway inflammation with ultrafine corticosteroid particle formulations or anti-IgE therapy in asthma patients with distal lung inflammation may provide a better outcome.

\section{Noninvasive Tools to Assess Inflammation of the Small Airways}

Noninvasive techniques to measure the composition of induced sputum, exhaled gases, and breath condensates were suggested as clinical methods for assessing small airway inflammation and oxidative stress in a number of lung diseases, including asthma. Most often, these techniques measure fractional exhaled nitric oxide (FeNO), which has been validated as a marker of sputum eosinophilic inflammation. This assessment is important since it has been shown that a sputum eosinophil count greater than $3 \%$ is responsive to corticosteroid treatment, whereas noneosinophilic asthma ( $<3 \%$ eosinophils) is less responsive to this intervention [37]. This clinically relevant threshold level of sputum eosinophilia has recently been associated with a threshold FeNO value of 42 ppb, which can be used to discriminate eosinophilic vs. noneosinophilic asthma and assess the efficacy of antiinflammatory treatment in a safe, rapid, and noninvasive manner [38]. Further refinements have been made to this technique to assess the central and peripheral contributions to total lung FeNO levels using a ventilation heterogeneity approach [39], while Williamson et al. [40] have proposed a novel method to correct for NO production in the conducting airways which allows for a more accurate assessment of alveolar NO production and eosinophilic inflammation. Beyond the assessment of FeNO/eosinophilia, the concentration of $N \varepsilon$-(carboxymethyl)lysine (CML), a marker of chronic inflammation and oxidative stress in alveolar epithelial cells, has been measured in induced sputum, with significantly higher levels found in asthmatic subjects [41]. In addition, several novel exhaled biomarkers for distal lung inflammation have recently been evaluated, including endothelin-1 [42], eotaxin-1 [43], RANTES [44], and hydrogen peroxide, all of which have been positively associated with inflammation. Interestingly, Sethi et al. [45] found that levels of exhaled carbon monoxide and nitric oxide were modulated by the type of bronchoprovocation test used [methacholine (MCh) vs. allergen], further demonstrating that an inflammatory stimulus, i.e. allergen challenge, has a direct positive effect on NO but not CO levels.

\section{Small Airway Remodeling}

In patients with fatal asthma, changes have been found to occur to the extracellular matrix (ECM) throughout the lung. In fatal asthma, these ECM changes were par- 
ticularly intense in the outer region of the wall of small airways, including increased deposition of fibronectin, collagen I and collagen III as well as increased expression of several metalloproteinases (MMP-1, MMP-2, and MMP-9). The changes in these regions were associated with perturbed alveolar attachments and thereby may contribute to airway-parenchymal uncoupling and altered mechanics of the distal lung. Although the direct impact of small airway remodeling on lung function has not yet been shown, remodeling in the lung periphery may be quite difficult to treat pharmacologically given the poor distal distribution of most currently available formulations of inhaled corticosteroids.

Regional variability in the phenotype of lung structural cells has been demonstrated recently in a study by Pechkovsky et al. [46] in which normal primary fibroblasts from the proximal and distal airways were assessed for their responses to TGF- $\beta$. It was found that distal fibroblasts showed evidence of enhanced baseline TGF- $\beta$ signaling and were a more myofibroblast-like phenotype with higher baseline expression of $\alpha$-smooth muscle actin [46]. Distal fibroblasts were also shown to be stiffer and more contractile compared to cells from proximal regions of the lung. The results of this study demonstrate that mesenchymal cells of the distal lung have an enhanced ability to differentiate into myofibroblasts under conditions of increased TGF- $\beta$ expression and mechanical tension. However, the contributions of these cells to distal lung fibrosis, as well as regional phenotypic differences in mesenchymal cell populations in asthmatics, have yet to be investigated.

\section{Small Airways: No Longer the Quiet Zone of the Lung}

Most of our knowledge of lung function in asthmatics comes from spirometric and plethysmographic measurements made during bronchoprovocation, and these measurements are dominated by large airway responsiveness. Since the volume and surface area of the bronchial tree increase with increasing airway generations, the contribution of peripheral resistance to the total lung resistance was originally thought to be minimal [21]. Research conducted over three decades ago, using retrograde catheters in animals, demonstrated that the distal airways are pathways of low resistance, contributing to less than $10 \%$ of the total resistance to airflow in the lung models [47, 48]. For this reason, the distal airways were originally described as the 'quiet zone' of the lungs in 1970 [49].
Since then, more sophisticated measurements of the peripheral airways have been developed, e.g. invasive studies in mongrel dogs using alveolar capsules to separately assess the mechanical properties of the airways and parenchyma or using the forced oscillation technique in rodents [50-52]. We have demonstrated that both airway and parenchymal compartments contribute to airway responsiveness. MCh-induced increase in parenchymal resistance has also been reported in New Zealand white rabbits [53, 54], guinea pigs [55], and rats [51, 56, 57].

Invasive studies have been carried out in patients with asymptomatic asthma using a catheter-tipped micromanometer wedged into the lower lobe of the bronchus in order to partition central and peripheral airway resistance. In these studies, the investigators constructed separate dose-response curves in vivo and showed a dosedependent increase in both central and peripheral airway resistance in response to inhaled $\mathrm{MCh}$ in all patients studied. More recently, noninvasive methodologies for separating airway and parenchymal mechanics both in animals $[58,59]$ and in humans $[60-63]$ have been developed. Using the low-frequency forced oscillation technique, Hall et al. [60] demonstrated in infants that inhaled MCh alters both central and peripheral airway mechanics as well as lung parenchymal mechanics. In healthy controls and in patients with chronic obstructive lung disease, the distal airway resistance contributes between 50 and $90 \%$ of the total lung resistance [64]. Van Brabandt et al. [64] concluded that the contribution of the distal airways to the total lung resistance has thus far been grossly underestimated and that the physiological outcome is largely dependent on the frequency used to measure the peripheral lung mechanics. They argued that this is because at high-frequency, low-amplitude oscillations the contribution of the distal airways to the total lung resistance is minimized, whereas at low-frequency, high-amplitude oscillations their contribution is maximized [64].

More recently peripheral airways, including lung tissue, have been recognized as a predominant site of airflow obstruction in asthmatics. In partitioning the central and peripheral airway resistance in awake humans, Yanai et al. [5] demonstrated a dramatically increased contribution of the distal airways to the total lung resistance in patients with moderate-to-severe asthma when compared to healthy subjects or to patients with mild asthma. In these patients, lung function measurements were performed in a single lobe of the lung and it may be argued this is not an accurate depiction of total lung resistance; however, these values were similar to those mea- 
sured throughout postmortem human lung specimens [65]. Furthermore, Wagner et al. [66] showed that in mild asthmatics with normal spirometry, the distal airway resistance was increased up to seven-fold when compared to controls and these measurements correlated with responsiveness to $\mathrm{MCh}$. In addition, asymptomatic asthmatics can exhibit significant increases in peripheral airway resistance, which is likely to be a result of distal lung inflammation. Computational analyses based on quantitative histology have shown the peripheral airways to account for the majority of the airway hyperresponsiveness among asthmatics [67].

\section{Conclusions}

There is accumulating evidence to suggest that airway inflammation occurs throughout the airway. Although the clinical significance of the small airway and the lung parenchymal involvement in asthma is not yet known, it is possible that poorly controlled inflammation in the distal airways, which is not penetrated by conventional inhaled steroids, may contribute to an accelerated decline in lung function and airway remodeling. Although the nature of airway wall remodeling has been reason- ably well described in the large airways, relatively little is known about structural remodeling of the distal airways.

There is a need to assess distal lung and parenchymal inflammation in asthma of different severities and at different ages. Accurate detection and early diagnosis of small airway dysfunction is important as treatment during early stages of the disease may be able to effectively reverse airway remodelling and progression to airway fibrosis and irreversible airway damage in mild-to-moderate asthmatics. There is also a need to identify an accurate way to assess distal airway inflammation noninvasively. The introduction of high-resolution computed tomography allows assessment of morphological changes in the distal airways that are associated with dysfunction too subtle to be identified on lung function testing alone [68]. This novel noninvasive imaging technique may prove to be important not only in the diagnosis of distal airway inflammation but also in helping us gain a better understanding of the role of the small airways and the parenchyma in the pathogenesis of allergic asthma.

We have learned a great deal about the peripheral airways with the help of new physiological and biochemical technologies; however, there are many questions which remain unanswered in this important area of research.

\section{References}

1 Dunnill MS: The pathology of asthma, with special reference to changes in the bronchial mucosa. J Clin Pathol 1960;13:27-33.

2 Curschmann H: Ueber Bronchiolitis exsudative und ihr Verhaltniss zum Asthma nervosum. Dtsch Arch Klin Med 1882;32:1-34.

-3 Levine G, Housley E, MacLeod P, Macklem PT: Gas exchange abnormalities in mild bronchitis and asymptomatic asthma. N Engl J Med 1970;282:1277-1282.

4 Despas PJ, Leroux M, Macklem PT: Site of airway obstruction in asthma as determined by measuring maximal expiratory flow breathing air and a helium-oxygen mixture. J Clin Invest 1972;51:3235-3243.

$\checkmark 5$ Yanai M, Sekizawa K, Ohrui T, Sasaki H, Takishima T: Site of airway obstruction in pulmonary disease: direct measurement of intrabronchial pressure. J Appl Physiol 1992; 72:1016-1023.

6 6 Ohrui T, Sekizawa K, Yanai M, Morikawa M, Jin Y, Sasaki H, Takishima T: Partitioning of pulmonary responses to inhaled methacholine in subjects with asymptomatic asthma. Am Rev Respir Dis 1992;146:1501-1505.
7 Kuwano K, Bosken CH, Pare PD, Bai TR, Wiggs BR, Hogg JC: Small airways dimensions in asthma and in chronic obstructive pulmonary disease. Am Rev Respir Dis 1993; 148:1220-1225.

8 Wagner EM, Bleecker ER, Permutt S, Liu MC: Direct assessment of small airways reactivity in human subjects. Am J Respir Crit Care Med 1998;157:447-452.

-9 Djukanovic R, Wilson JW, Lai CK, Holgate ST, Howarth PH: The safety aspects of fiberoptic bronchoscopy, bronchoalveolar lavage, and endobronchial biopsy in asthma. Am Rev Respir Dis 1991;143:772-777.

10 Bentley AM, Meng Q, Robinson DS, Hamid Q, Kay AB, Durham SR: Increases in activated T lymphocytes, eosinophils, and cytokine mRNA expression for interleukin-5 and granulocyte/macrophage colony-stimulating factor in bronchial biopsies after allergen inhalation challenge in atopic asthmatics. Am J Respir Cell Mol Biol 1993;8:35-42.

- 11 Hamid Q, Song Y, Kotsimbos TC, Minshall E, Bai TR, Hegele RG, Hogg JC: Inflammation of small airways in asthma. J Allergy Clin Immunol 1997;100:44-51.
12 Minshall EM, Hogg JC, Hamid QA: Cytokine mRNA expression in asthma is not restricted to the large airways. J Allergy Clin Immunol 1998;101:386-390.

13 Taha RA, Minshall EM, Miotto D, Shimbara A, Luster A, Hogg JC, Hamid QA: Eotaxin and monocyte chemotactic protein- 4 mRNA expression in small airways of asthmatic and nonasthmatic individuals. J Allergy Clin Immunol 1999;103:476-483.

14 Carroll N, Cooke C, James A: The distribution of eosinophils and lymphocytes in the large and small airways of asthmatics. Eur Respir J 1997;10:292-300.

15 Faul JL, Tormey VJ, Leonard C, Burke CM, Farmer J, Horne SJ, Poulter LW: Lung immunopathology in cases of sudden asthma death. Eur Respir J 1997;10:301-307.

16 Christodoulopoulos P, Leung DY, Elliott MW, Hogg JC, Muro S, Toda M, Laberge S, Hamid QA: Increased number of glucocorticoid receptor-beta-expressing cells in the airways in fatal asthma. J Allergy Clin Immunol 2000;106:479-484. 
$>17$ Kraft M, Djukanovic R, Wilson S, Holgate ST, Martin RJ: Alveolar tissue inflammation in asthma. Am J Respir Crit Care Med 1996; 154:1505-1510.

-18 Kraft M, Martin RJ, Wilson S, Djukanovic R, Holgate ST: Lymphocyte and eosinophil influx into alveolar tissue in nocturnal asthma. Am J Respir Crit Care Med 1999;159:228234.

19 Carroll N, Carello S, Cooke C, James A: Airway structure and inflammatory cells in fatal attacks of asthma. Eur Respir J 1996;9: 709-715.

-20 Synek M, Anto JM, Beasley R, Frew AJ, Holloway L, Lampe FC, Lloreta JL, Sunyer J, Thornton A, Holgate ST: Immunopathology of fatal soybean dust-induced asthma. Eur Respir J 1996;9:54-57.

21 Weibel ER: Morphometry of the Human Lung. New York, Academic Press, 1963.

22 Woolcock AJ: Effect of drugs on small airways. Am J Respir Crit Care Med 1998; 157:S203-207.

$\checkmark 23$ James AL, Pare PD, Hogg JC: The mechanics of airway narrowing in asthma. Am Rev Respir Dis 1989;139:242-246.

24 Huber HL, Koessler KK: The pathology of bronchial asthma. Arch Intern Med 1922;30: 689-760.

25 Haley KJ, Sunday ME, Wiggs BR, Kozakewich HP, Reilly JJ, Mentzer SJ, Sugarbaker DJ, Doerschuk CM, Drazen JM: Inflammatory cell distribution within and along asthmatic airways. Am J Respir Crit Care Med 1998; 158:565-572.

26 Hamid QA: Peripheral inflammation is more important than central inflammation. Respir Med 1997;91(suppl A):11-12.

-27 Saetta M, Di Stefano A, Rosina C, Thiene G, Fabbri LM: Quantitative structural analysis of peripheral airways and arteries in sudden fatal asthma. Am Rev Respir Dis 1991;143: 138-143.

28 Kraft M: The distal airways: are they important in asthma? Eur Respir J 1999;14:14031417.

29 Kraft M, Vianna E, Martin RJ, Leung DY: Nocturnal asthma is associated with reduced glucocorticoid receptor binding affinity and decreased steroid responsiveness at night. J Allergy Clin Immunol 1999;103:66-71.

-30 Wenzel SE, Szefler SJ, Leung DY, Sloan SI, Rex MD, Martin RJ: Bronchoscopic evaluation of severe asthma: persistent inflammation associated with high dose glucocorticoids. Am J Respir Crit Care Med 1997;156: 737-743.

-31 Kuyper LM, Pare PD, Hogg JC, Lambert RK, Ionescu D, Woods R, Bai TR: Characterization of airway plugging in fatal asthma. Am J Med 2003;115:6-11.

- 32 Boulet LP: Transbronchial biopsy as a tool to evaluate small-airways disease in asthma: pros. Eur Respir J 2002;20:247-248.
Andersson CK, Bergqvist A, Mori M, Mauad T, Bjermer L, Erjefalt JS: Mast cell-associated alveolar inflammation in patients with atopic uncontrolled asthma. J Allergy Clin Immunol 2011;127:905-912 e901-907.

34 Balzar S, Chu HW, Strand M, Wenzel S: Relationship of small airway chymase-positive mast cells and lung function in severe asthma. Am J Respir Crit Care Med 2005;171: 431-439.

35 Bentley AM, Hamid Q, Robinson DS, Schotman E, Meng Q, Assoufi B, Kay AB, Durham SR: Prednisolone treatment in asthma: reduction in the numbers of eosinophils, $\mathrm{T}$ cells, tryptase-only positive mast cells, and modulation of IL-4, IL-5, and interferongamma cytokine gene expression within the bronchial mucosa. Am J Respir Crit Care Med 1996;153:551-556.

36 Booth H, Richmond I, Ward C, Gardiner PV, Harkawat R, Walters EH: Effect of high dose inhaled fluticasone propionate on airway inflammation in asthma. Am J Respir Crit Care Med 1995; 152:45-52.

37 Pavord ID, Brightling CE, Woltmann G, Wardlaw AJ: Non-eosinophilic corticosteroid unresponsive asthma. Lancet 1999;353: 2213-2214.

- 38 Schleich FN, Seidel L, Sele J, Manise M, Quaedvlieg V, Michils A, Louis R: Exhaled nitric oxide thresholds associated with a sputum eosinophil count $\geq 3 \%$ in a cohort of unselected patients with asthma. Thorax 2010; 65:1039-1044.

- 39 Verbanck S, Schuermans D, Vincken W: Inflammation and airway function in the lung periphery of patients with stable asthma. J Allergy Clin Immunol 2010;125:611-616.

40 Williamson PA, Clearie K, Menzies D, Vaidyanathan S, Lipworth BJ: Assessment of small-airways disease using alveolar nitric oxide and impulse oscillometry in asthma and COPD. Lung 2011;189:121-129.

41 Kanazawa H, Kyoh S, Asai K, Hirata K: Validity of measurement of two specific biomarkers for the assessment of small airways inflammation in asthma. J Asthma 2010;47: 400-406.

42 Zietkowski Z, Skiepko R, Tomasiak-Lozowska MM, Bodzenta-Lukaszyk A: Anti-IgE therapy with omalizumab decreases endothelin-1 in exhaled breath condensate of patients with severe persistent allergic asthma. Respiration 2010;80:534-542.

43 Zietkowski Z, Tomasiak-Lozowska MM, Skiepko R, Zietkowska E, Bodzenta-Lukaszyk A: Eotaxin-1 in exhaled breath condensate of stable and unstable asthma patients. Respir Res 2010;11:110.

44 Zietkowski Z, Skiepko R, Tomasiak-Lozowska MM, Lenczewska D, Bodzenta-Lukaszyk A: Rantes in exhaled breath condensate of patients with severe persistent allergic asthma during omalizumab therapy. Int Arch Allergy Immunol 2011;154:25-32.
45 Sethi JM, White AM, Patel SA, Dinella JV, Calhoun WJ, Choi AM: Bronchoprovocation testing in asthma: effect on exhaled monoxides. J Breath Res 2010;4:047104.

-46 Pechkovsky DV, Hackett TL, An SS, Shaheen F, Murray LA, Knight DA: Human lung parenchyma but not proximal bronchi produces fibroblasts with enhanced TGF-beta signaling and alpha-SMA expression. Am J Respir Cell Mol Biol 2010;43:641-651.

47 Macklem PT, Mead J: Resistance of central and peripheral airways measured by a retrograde catheter. J Appl Physiol 1967;22:395-401.

- 48 Brown R, Woolcock AJ, Vincent NJ, Macklem PT: Physiological effects of experimental airway obstruction with beads. J Appl Physiol 1969;27:328-335.

49 Mead J, Takishima T, Leith D: Stress distribution in lungs: a model of pulmonary elasticity. J Appl Physiol 1970;28:596-608.

50 Hall GL, Petak F, McMenamin C, Sly PD: The route of antigen delivery determines the airway and lung tissue mechanical responses in allergic rats. Clin Exp Allergy 1999;29: 562-568.

51 Petak F, Hantos Z, Adamicza A, Asztalos T, Sly PD: Methacholine-induced bronchoconstriction in rats: effects of intravenous vs. aerosol delivery. J Appl Physiol 1997;82: 1479-1487.

52 Suki B, Petak F, Adamicza A, Hantos Z, Lutchen KR: Partitioning of airway and lung tissue properties: comparison of in situ and open-chest conditions. J Appl Physiol 1995; 79:861-869.

53 Romero PV, Robatto FM, Simard S, Ludwig MS: Lung tissue behavior during methacholine challenge in rabbits in vivo. J Appl Physiol 1992;73:207-212.

54 Tepper R, Sato J, Suki B, Martin JG, Bates JH: Low-frequency pulmonary impedance in rabbits and its response to inhaled methacholine. J Appl Physiol 1992;73:290-295.

55 Ingenito EP, Davison B, Fredberg JJ: Tissue resistance in the guinea pig at baseline and during methacholine constriction. J Appl Physiol 1993;75:2541-2548.

56 Salerno FG, Moretto A, Dallaire M, Ludwig MS: How mode of stimulus affects the relative contribution of elastance and hysteresivity to changes in lung tissue resistance. J Appl Physiol 1995;78:282-287.

57 Tulic MK, Wale JL, Petak F, Sly PD: Muscarinic blockade of methacholine induced airway and parenchymal lung responses in anaesthetised rats. Thorax 1999;54:531-537.

58 Preuss JM, Hall GL, Sly PD: Repeat measurement of respiratory mechanics using the forced oscillation technique in non-paralysed rats. Pulm Pharmacol Ther 1999;12: 173-183.

59 Petak F, Hall GL, Sly PD: Repeated measurements of airway and parenchymal mechanics in rats by using low-frequency oscillations. J Appl Physiol 1998;84:1680-1686. 
60 Hall GL, Hantos Z, Wildhaber JH, Petak F, Sly PD: Methacholine responsiveness in infants assessed with low frequency forced oscillation and forced expiration techniques. Thorax 2001;56:42-47.

61 Hall GL, Hantos Z, Petak F, Wildhaber JH, Tiller K, Burton PR, Sly PD: Airway and respiratory tissue mechanics in normal infants. Am J Respir Crit Care Med 2000;162: 1397-1402.

62 Hayden MJ, Petak F, Hantos Z, Hall G, Sly PD: Using low-frequency oscillation to detect bronchodilator responsiveness in infants. Am J Respir Crit Care Med 1998;157: 574-579.
63 Sly PD, Hayden MJ, Petak F, Hantos Z: Measurement of low-frequency respiratory impedance in infants. Am J Respir Crit Care Med 1996;154:161-166.

64 Van Brabandt H, Cauberghs M, Verbeken E, Moerman P, Lauweryns JM, Van de Woestijne KP: Partitioning of pulmonary impedance in excised human and canine lungs. J Appl Physiol 1983;55:1733-1742.

65 Hogg JC, Macklem PT, Thurlbeck WM: Site and nature of airway obstruction in chronic obstructive lung disease. N Engl J Med 1968; 278:1355-1360.

66 Wagner EM, Liu MC, Weinmann GG, Permutt S, Bleecker ER: Peripheral lung resistance in normal and asthmatic subjects. Am Rev Respir Dis 1990;141:584-588.
67 Wiggs BR, Bosken C, Pare PD, James A, Hogg JC: A model of airway narrowing in asthma and in chronic obstructive pulmonary disease. Am Rev Respir Dis 1992;145: 1251-1258.

68 Goldin JG, Tashkin DP, Kleerup EC, Greaser LE, Haywood UM, Sayre JW, Simmons MD, Suttorp M, Colice GL, Vanden Burgt JA, Aberle DR: Comparative effects of hydrofluoroalkane and chlorofluorocarbon beclomethasone dipropionate inhalation on small airways: assessment with functional helical thin-section computed tomography. J Allergy Clin Immunol 1999;104:S258-S267. 